\title{
THE IMPACT OF KOJA CLIFF DEVELOPMENT ON SOCIAL-CULTURAL AND ECONOMIC: CASE OF COMMUNITY-BASED TOURISM, BANTEN, INDONESIA
}

\author{
Fakhri RAFI \\ Universitas Indonesia, School of Enviromental Science, Jl. Salemba Raya No. 4, \\ Central Jakarta, Jakarta 10430, Indonesia, e-mail: fakhri_rafi@yahoo.co.id

\section{Herdis HERDIANSYAH*} \\ Universitas Indonesia, School of Enviromental Science, Jl. Salemba Raya No. 4, \\ Central Jakarta, Jakarta 10430, Indonesia, e-mail: herdis@ui.ac.id
}

\begin{abstract}
Citation: Rafi, F. \& Herdiansyah, H. (2020). THE IMPACT OF KOJA CLIFF DEVELOPMENT ON SOCIAL-CULTURAL AND ECONOMIC: CASE OF COMMUNITY-BASED TOURISM, BANTEN, INDONESIA. GeoJournal of Tourism and Geosites, 28(1), 164-174. https://doi.org/10.30892/gtg.28113-460
\end{abstract}

\begin{abstract}
Indonesia has a great geotourism potential formed both naturally and engineered. Koja Cliff is an example of the latter built in the former mining area in Banten Province by local community. The purpose of this research was description geotourism development and relationship among economy and social-cultural for community-based-tourism in Koja Cliff, Banten, Indonesia. The research investigated with 39 respondents as a regular traveler to Koja Cliff and using puposive sampling method. Geotourism descriptive, validity, reliability, and multiple regression were conducted to answer research questions. This research finding shows Koja Cliff as had directly positive influences on social-cultural and economic of community-based tourism.
\end{abstract}

Key words: geotourism, community-based tourism, social-cultural, economic, Banten

\section{INTRODUCTION}

Indonesia's tourism is one of the factor, that has good industrial potential with demand and tourist visits reaching 14 million people in 2017 (OECD, 2018). In general, tourism has an impact on three things, namely economics, social-culture, and environment which have an effect on the community around the tourism area (Cooper et al., 2008). Increasing demand for tourism products in Indonesia can be viewed at the stage of tourist arrivals that continue to increase from year to year. The country of Indonesia is unique in its geological diversity because it is located in the Pacific circum and between three large continental plates (Santosh et al., 2009).

\footnotetext{
* Corresponding author
} 
Indonesia's geological diversity can be utilized to develop areas in the field of tourism, commonly called Geotourism. Geotourism has been assessed as important for tourism (Pralong, 2006; Piacentini et al., 2011; Cappucci et al., 2015).

Geotourism is a new approach in developing countries (Farsani et al., 2018). Indonesia has great potential because it has geological diversity which is spread throughout the region, some places need to be made as geological heritage areas (Yuliawati et al., 2016). Geotourism is one solution that is strong enough to protect the environment. These alternative solutions can provide better sector relations, reduce leakage of benefits from a country, create local jobs, and foster sustainable development. But Geotourism is still a phenomenon in the paradigm of developing tourism, especially in Indonesia (Khan, 1997). Large geotourism potential exists naturally and artificially formed. Former mining areas can be a potential for geotourism that is unique and rarely found in other areas and then provides an opportunity for the community to manage it.

Achieving development must have a significant influence on people's welfare (Kodir, 2018). Man-made tourism is currently demanded to be innovative and creative in packaging tourism strategies to attract more local and foreign tourists (Carvalho \& Costa, 2011) and requires support from various parties needed for long-term sustainability of man-made tourism (Muafi et al., 2018). This study explore a discussion of ex-mining geotourism by examining the impact of geotourism on the economy and social-culture of local communities. The research conducted focuses on the economic and social-cultural investigation of community-based tourism. Geotourism potential from the former mining area that has been managed by the community in the past year is Koja Cliff, so research is needed. This study aims to add to the case study evidence by adding economic and social-cultural aspects. These objectives can be achieved with hypotheses developed that Economics and social-culture simultaneously related to geotourism.

\section{LITERATURE REVIEW Geotourism}

Geotourism became known after geology scientist, Tom Hose, in 1995 introduced and published the term which was related to the provision of interpretative purposes for Geoconservation geosites and geomorphosites such as museums, libraries and archive collections, along with artistic output (Hose et al., 2011). The development of geotourism then becomes a holistic approach to sustainable tourism that brings culture, history and nature. This approach is to maximize the use of tourism for community destinations, minimize negative impacts, and establish responsible tourism strategies (Stokes et al., 2003; Gordon, 2012; Dowling, 2013). Tourists also need motivation to visit Geotourism destinations to achieve satisfaction (Shavanddasht, 2017).

Now geotourism is a favorite that is used to encourage sustainable tourism development in various regions of Indonesia. Research to support the development of geotourism such as the construction of geopark is in Ciletuh, Sukabumi (Yuliawati, 2016), biodiversity conversation at Bromo, Malang (Hakim \& Soemarno, 2017), geoconservation in Toba, North Sumatra (Ginting et al., 2017), value indigenous culture on Sabang Island, Aceh (Aswita et al., 2018), and geoheritage in Batur, Bali (Rosyidie et al., 2018).

\section{Community-Based Tourism}

Tourism growth is increasing so that in order to develop tourism it needs the necessary effort. Meanwhile, community participation is an important part of tourism development because it allows many stakeholders to build strong political leadership and joint consensus efforts to build community participation; delegates propose ideas in developing active community participation (Komarudin, 2013). One effort that can invite 
local communities around tourism is community-based tourism. These efforts made stakeholders to make meetings in the Asia Pacific, especially for developing countries.

The community-based tourism at the tourism ministerial meeting was first emphasized with the establishment of the Tourism Charter in Asia Pacific Economic Cooperation (APEC) in Korea in 2000 (APEC, 2000). Community-based tourism must be able to increase sustainable value and long-term sustainability which will depend on how well the stakeholders address new expectations (The Mountain Institute, 2000). Furthermore, Community-based tourism programs can show expertise by producing a variety of tangible products to tourists (Vinodan et al., 2017). The opportunity for the community is to be able to participate in Community-based tourism for planning, development and decision making in tourism, especially Geotourism.

\section{Social-Cultural}

Tourism influences the social-culture of the surrounding community (Yoon et al., 2001; Eshliki \& Kaboudi, 2012; Chin et al., 2014; Lundberg, 2017). Therefore, socialcultural effects can sometimes be related to quality of life, values, norms, community models and environmental damage (Deery et al., 2012). The lives of people around tourist destinations are more dynamic because they can interact easily with tourists, be able to think broadly, imitate good habits, understand people's habits, want to preserve local culture, accept differences, be able to meet basic needs and encourage people to contribute to tourist activities (Pramanik \& Ingkadijaya, 2018).

Social-culture of society also has an influence with the existence of tourism. Eraqi (2007) revealed that tourism development in Egypt provides social-cultural benefits because of the positive value of cultural exchange. However, in contrast to research in Iran, people at 54.9 percent consider many negative impacts of tourism development such as the death of local languages, eliminating local habits, and local clothing (Farsani et al., 2012). Furthermore, on Mount Pinatubo, the Philippine tourists are inspired and amazed at the resilience of indigenous peoples so tourists introspect themselves with their own lifestyles (Aquino et al., 2018).

\section{Economic}

Tourism which is a tourist destination from outside will have a positive impact on the economy of the surrounding community so that they get better income. Employment will be open to the community. The tourism business will run well if there is access to infrastructure and public transportation. The future of tourism is expected to be better because global indicators show that tourism's contribution to GDP (Gross Domestic Product) is 9 percent or around USD 6 Trillion per year and creates 260 million jobs worldwide with an average growth of $4 \%$ of the year 2011 to 2021 (Tsiotsu \& Goldsmith, 2012). Regional tourism can encourage and improve the regional economy through Geotourism (Ginting \& Sasmita, 2018; Arjana et al., 2017).

The economy based on the community has a relationship with Geotourism. Dowling and Newsome (2010) argue that community participation will produce an economy for the services provided to tourists during their time at the Geotourism location. High community contributions to Geotourism will provide economic benefits and increase the local economic value of the area. The community economy can increase because they participate in the development of Geotourism. Geo-tourism from geomorphology in Marocco shows economic interest as evidenced by the presence of hundreds of tourists (Bouzekraoui et al., 2017). Then the public perception in the Toba Caldera shows that there is a community economic growth (Ginting \& Febriandy, 2018).

Economic alternatives such as Geotourism need to be considered with activities planned for development (Mero et al., 2018). Figure 1 illustrates the concetual framework 
of geotourism. In short, there are many literatures which focus on economics, socialculture and Geotourism. This study aims at Geotourism managed by community-based tourism and has a positive influence on the economic and social-cultural aspects of society.

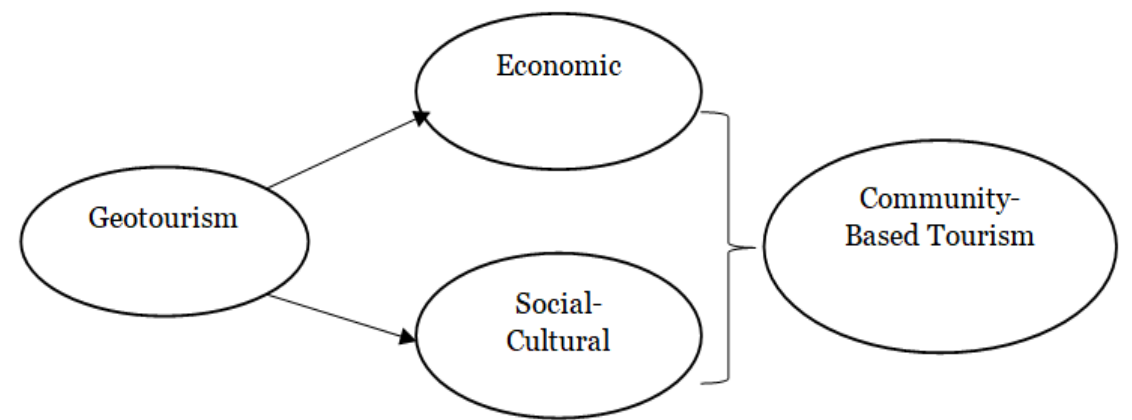

Figure 1. Conceptual framework of geotourism

(Source: Cooper et al., 2008; Cottrel \& Shen, 2008; Pan et al., 2018)

\section{METHODOLOGY}

This study uses a qualitative approach. The approach is chosen based on the character of the study which describes a narrow area, simple variables, meanings, and research data by analysis. The research method used was quantitative methods and qualitative methods (mix methods) which were collected in October-November 2018 in Cikuya Village, Banten, Indonesia. Qualitative methods generally refer to the rules of reduction and triangulation of data from interview result.

In-depth and open interviews are conducted with Geotourism managers, namely communities that get direct economic benefits from the geography of Koja Cliff. Socialcultural interviews with managers of community communities regarding openness and exchanging social-culture to visitors of Geotourism of Koja Cliff from various regions in Indonesia. This data is collected quantitative data to analyze empirical data from responses through questionnaire surveys. Quantitative samples were selected from as a regular traveler to Koja Cliff because they included a type of non-probability sampling, so purposive sampling was chosen. Purposive sampling is a type of non-probability sampling where samples are selected from a group of people who have a direct influence on Geotourism (Sauders et al., 2016). Empirical data from respondents was measured using a Likert type scale with five term categories from "1-Strong Disagree" to "5-Strongly Agree". The data was analyzed using Statistical Package Social Science (SPSS).

\section{RESULTS}

\section{Regional Overview}

Koja Cliff geotourism began to be developed into tourism in March 2017. This geotourism is located on the border of Tangerang Regency and Serang Regency, and $60 \mathrm{~km}$ from southwest of DKI Jakarta. Geotourism placed on latitude 6 ${ }^{\circ} 18^{\prime} 50.4^{\prime \prime S}$ and $6^{\circ} 18^{\prime} 57.6^{\prime \prime}$ $\mathrm{S}$, longitude $106^{\circ} 23^{\prime} 34.8^{\prime \prime E}$ and $106^{\circ} 23^{\prime} 42^{\prime \prime}$ E. Administratively, the Koja Cliff is in Koja Village, Cikuya Village, Tangerang Regency, Banten Province (Figure 2). There are two access routes to the Koja Cliff Geotourism from Balaraja in the North and Maja in the South. Geologically, Koja Cliff geotourism has an important landscape designation regarding the geological history of the Banten area. The geological process in Cikuya Village is a storage area for rock types produced by volcanoes. This is shown in the geological map of the existence of tuffaceous sandstones on very hard cliffs and quaternary (Rusmana et al., 1991). 


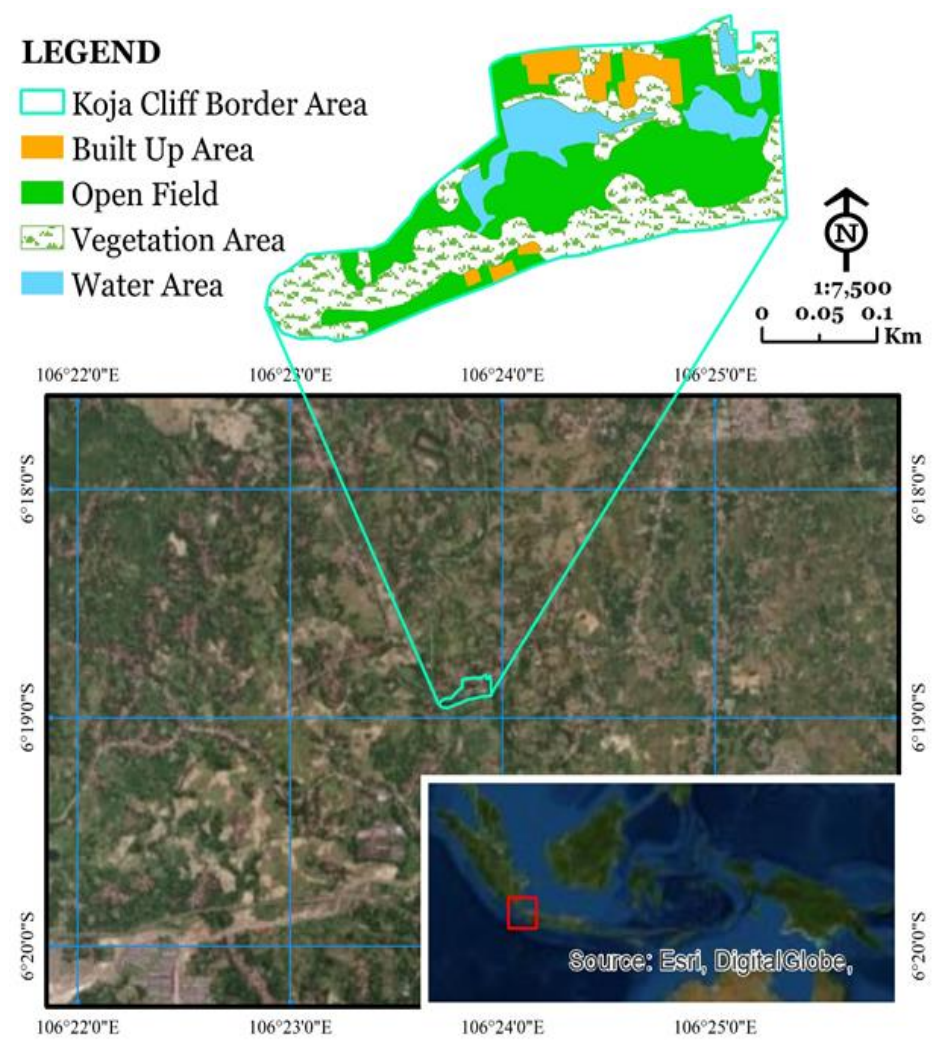

Figure 2. Location map of Koja Cliff

Koja Cliff is a short cliff formed by sedimentary volcanic products. The cliff length is around $200 \mathrm{~m}$ and $50 \mathrm{~cm}$ wide, has a dominant form of tuffaceous sandstone unit. The Koja Cliff was not used to being because they were underground and because they were rice fields. Because of the economic factors, the landowners discovered the potential of $\mathrm{C}$ excavation material to be sold in the period 2009-2016, so that it gave the morphological form as it is now. Cliff is not excavated because it has high violence and landowners do not have the technology to dig the rock because they still use traditional methods to dig sand. After being abandoned there are people seeing the potential of Geotourism in excavated areas because of the unique morphological forms and beauty that are quite rare in the surrounding area. Geotourism grows on the Koja Cliff as an alternative tourist attraction around Jakarta, which is a safe and sustainable geological resource. Every geotourism traveler must walk around the cliff area to get a popular landscape and be able to achieve satisfaction in this geotourism as captured in Figure 3.

Koja cliff tourism has an increasing number of tourists so that many people begin to take part in tourism community communities to increase their income. One part of the community that joins the tourist community is as a trader who sells snacks and drinks as well as shady places for tourists. Then one of the community members in the tourist community followed as a motorcycle taxi (driver) who escorted and picked up visitors from several points around public transportation to visit the Koja cliffs. Local workers who joined the community began to be distributed throughout most villages, although they were still dominated by landowners' relatives. 
The Impact of Koja Cliff Development on Social-Cultural and Economic: Case of Community-Based Tourism, Banten, Indonesia

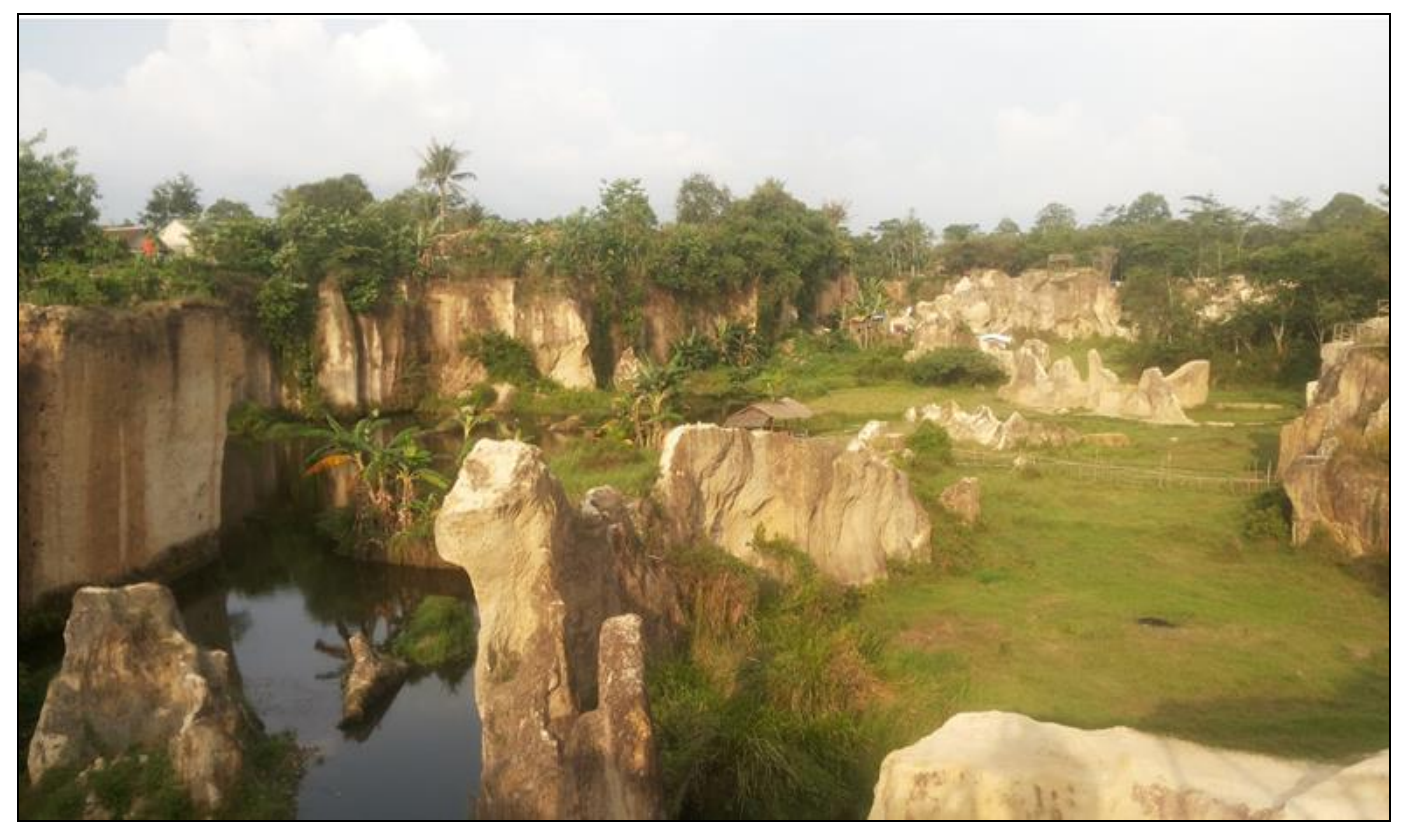

Figure 3. Popular view point of Koja Cliff

Table 1. Demographic variables of the respondents

\begin{tabular}{|c|c|c|}
\hline \multicolumn{2}{|c|}{ Variables } & Respondent Profile (\%) \\
\hline \multirow{2}{*}{ Gender } & Male & 76.93 \\
\hline & Female & 23.07 \\
\hline \multirow{4}{*}{ Age (years old) } & $18-28$ & 30.59 \\
\hline & $29-39$ & 23.07 \\
\hline & $40-50$ & 30.86 \\
\hline & $>50$ & 15.38 \\
\hline \multirow{2}{*}{ Martial Status } & Married & 94.85 \\
\hline & Unmarried & 5.15 \\
\hline \multirow{3}{*}{$\begin{array}{l}\text { The Number of } \\
\text { Children (person) }\end{array}$} & None & 7.69 \\
\hline & $1-2$ & 30.96 \\
\hline & $\geq 3$ & 61.35 \\
\hline \multirow{4}{*}{ Education } & None & 7.69 \\
\hline & Elementary School & 38.56 \\
\hline & Junior High School & 20.51 \\
\hline & Senior High School & 33.24 \\
\hline \multirow{6}{*}{ Occupation } & Tourism & 35.89 \\
\hline & Farmers & 5.15 \\
\hline & Seller & 28.20 \\
\hline & Employee (non-formal) & 7.69 \\
\hline & Employee (formal) & 7.69 \\
\hline & Other (Driver) & $15 \cdot 38$ \\
\hline \multirow{5}{*}{$\begin{array}{l}\text { Income per month } \\
\text { (Thousand Rupiah) }\end{array}$} & $<600$ & 5.15 \\
\hline & $600-1,000$ & 30.96 \\
\hline & $1,000-1,800$ & 17.94 \\
\hline & $1,800-<3,000$ & 38.56 \\
\hline & $>3,000$ & 7.69 \\
\hline
\end{tabular}




\section{Data Analysis}

The type of respondents is the tourists who regularly visit Koja Cliff. before filling out the questionnaire, first asked how often respondents visist to Koja Cliff and only those who are more than once in 2 months are selected respondents.

The analysis includes description analysis, frequency analysis, validity test and reliability test which is then analyzed by multiple linear regression. The frequency analysis was conducted to analyze data regarding the profile of respondents. Frequency analysis of respondents' profiles can be seen in table 1. Descriptive analysis concluded that there were 39 respondents surveyed, respondents were dominated by male (76.93\%), aged 40-50 years (30.86\%), married (94.85\%), number of children $\geq 3$ (61.35\%), primary school education level (38.56\%), employment as tourism (35.89\%), and income 1,800- $<3,000$ in thousand rupiahs amounting to (38.56\%).

Validity and reliability were carried out by the questionnaire results of the respondents regarding economic, social-cultural and Geotourism. Test the validity of the correlation of Pearson seen from the total aspects with a value $>0.2673$, then the data is valid. Pearson correlation values from 25 statements are between of 0.2890 to 0.9210 . The results of the validity test show that 25 statements are valid.

Table 2. Validity and reability coefficients of indenpendent variables

\begin{tabular}{|c|c|c|c|c|}
\hline & \begin{tabular}{|c|}
$\begin{array}{c}\text { Indenpendent } \\
\text { Variables }\end{array}$ \\
\end{tabular} & Indicator & \begin{tabular}{|c|}
$\begin{array}{c}\text { Pearson } \\
\text { Correlation }\end{array}$ \\
\end{tabular} & $\begin{array}{c}\text { Cronbach's } \\
\text { Alpha }\end{array}$ \\
\hline & \multirow{7}{*}{ Social-Cultural } & Preservation of arts and culture & 0.560 & \multirow{7}{*}{0.612} \\
\hline & & Behavior of community & 0.829 & \\
\hline & & Moral values of community & 0.823 & \\
\hline & & The way think of community changes & 0.509 & \\
\hline & & Traffic congestion in the surrounding area & 0.467 & \\
\hline & & Noise in village & 0.389 & \\
\hline & & Religious activity & 0.389 & \\
\hline \multirow{10}{*}{2} & \multirow{10}{*}{ Economic } & Creating new jobs opportunities & 0.779 & \multirow{10}{*}{0.743} \\
\hline & & Development of school facilities & 0.289 & \\
\hline & & Development of health facilities & 0.650 & \\
\hline & & Construction of road access & 0.644 & \\
\hline & & Development of sports and entertainment facilities & 0.427 & \\
\hline & & Increase community's purchasing power & 0.644 & \\
\hline & & Increase community income & 0.320 & \\
\hline & & Community's quality life improving & 0.921 & \\
\hline & & The livelihood of community changes & 0.655 & \\
\hline & & Development of hygiene facilities & 0.330 & \\
\hline
\end{tabular}

In the reliability test, it is done to determine the questionnaire that can be used more than once, at least the same respondents will produce consistent data. Reliability testing using Cronbach'Alpha, data can be relied upon if the value of Cronbach'Alpha is 0.60 and that is good data. The reliability test results show the value of Cronbach'Alpha is between of 0.612 to 0.767 which is reliability data. Likewise the validity and reliability of the dependent ranges from 0.342 to 0.901 and the Cronbach'Alpha 0.767 value is shown in table 2. Correlation value $(\mathrm{R}=0.939)$ in Table 4 shows that high relationship of independent variable on dependent variable. Then, social-culture and economy in Table 4 shows that it has an influence of $88.2 \%$ on geotourism $\left(\mathrm{R}^{2}=0.882\right)$. In Table 5 in the $\mathrm{T}$ test, economic variables have their own / partial influence on the geotourism variable. Unlike the economy, social-cultural variables have no partial influence on geotourism 
The Impact of Koja Cliff Development on Social-Cultural and Economic: Case of Community-Based Tourism, Banten, Indonesia

variables. The $\mathrm{F}$ test provides information that economic and social-cultural variables have a simultaneous / joint effect on the geotourism variable.

Table 2 Validity and reability coefficients of dependent variable

\begin{tabular}{|c|c|c|c|}
\hline $\begin{array}{c}\text { Dependent } \\
\text { Variable }\end{array}$ & Statement & $\begin{array}{c}\text { Pearson } \\
\text { Correlation }\end{array}$ & $\begin{array}{c}\text { Cronbach's } \\
\text { Alpha }\end{array}$ \\
\hline & Important to be managed by community & 0.618 & \\
\cline { 2 - 3 } & $\begin{array}{c}\text { Community is involved in geotourism } \\
\text { management }\end{array}$ & 0.772 & \\
\cline { 2 - 3 } & $\begin{array}{c}\text { Cooperation between government and } \\
\text { community }\end{array}$ & 0.432 & \multirow{2}{*}{0.767} \\
\cline { 2 - 3 } & Rules in community to manage geotourism & 0.901 & \\
\cline { 2 - 3 } & Sanctions or penalties in management & 0.452 & \\
\cline { 2 - 3 } & Management regarding with local wisdom & 0.764 & \\
\cline { 2 - 3 } & Community and government receive benefit & 0.526 & \\
\cline { 2 - 3 } & $\begin{array}{c}\text { Migrant communities need to obey rules in } \\
\text { geotourism management }\end{array}$ & 0.624 & \\
\hline
\end{tabular}

Table 4. The result of regression analysis

\begin{tabular}{|l|l|l|l|l|}
\hline Model & $\mathrm{R}$ & R Square & Adjusted R Square & Std. Error of the Estimate \\
\hline 1 & $0.939^{\mathrm{a}}$ & 0.882 & 0.876 & 1.058 \\
\hline a. Indenpendent Variable: Social-Cultural, Economic \\
\hline b. Dependent Variable: Geotourism \\
\hline
\end{tabular}

Table 5. The result of Coefficients a between variable

\begin{tabular}{|l|c|c|c|c|c|c|}
\hline \multirow{2}{*}{ Model } & \multicolumn{2}{|c|}{ Unstandardized Coefficients } & $\begin{array}{c}\text { Standardized } \\
\text { Coefficients }\end{array}$ & \multirow{2}{*}{$\mathrm{t}$} & Sig. \\
\cline { 3 - 7 } \multicolumn{2}{|c|}{} & B & Std. Error & Beta & & \\
\hline \multirow{3}{*}{1} & (Constant) & -4.955 & 2.357 & & -2.103 & 0.043 \\
\cline { 2 - 6 } & Social-Cultural & 0.110 & 0.056 & 0.115 & 1.965 & 0.057 \\
\cline { 2 - 7 } & Economic & 0.855 & 0.055 & 0.907 & 15.480 & 0.000 \\
\hline \multicolumn{7}{|l|}{ a. Dependent Variabel: Geotourism } \\
\hline
\end{tabular}

\section{DISCUSSION}

This exploration depicts the underlying procedure of geotourism in Koja Cliff, Banten. The start is just as sand uncovering to address network issues. After the sand exhuming is finished, the spot structures morphology that is unique and significant as geotourism for scholastic realizing so network based the travel industry is shaped to oversee geotourism. At that point this investigation recognizes the presence of socialcultural impacts and the economy related with geotourism oversaw by network based the travel industry. This examination is a blend of a few factors that are impacted by the nearness of geotourism. Moreover, it turns into the test of geotourism oversaw by network based the travel industry which has social-social relationships and financial aspects in the territory (See e.g. Farsani et al., 2012; Kodir, 2018; Pramanik \& Ingkadijaya, 2018). In addition, the statistical results show that social-cultural does not have a partial influence on geotourism due to differences in the conditions of the community. But things are different from the economy which has a partial influence on geotourism because of the direct effect on the economy of the local community. Geotourism has a simultaneous influence on social-cultural and economic managed by 
community-based tourism which is worth $88.2 \%$. This research shows that concepts are made in accordance with the findings, with notes simultaneously (Cooper et al., 2008). This result, geotourism can be used by developing countries in developing their economies and social-cultural background simultaneously.

This study, the complexity of geotourism variables and methodologies (Sauders et al., 2016) can be a challenge because Indonesia has begun to depend on its income in the tourism sector and requires a lot of tourist data to see its potential. The government is also doubtful because its performance in Indonesia is still not good for the community so that the community itself is building the tourism. The potential of geotourism in this study is about social-cultural and economic, while (Shavanddasht et al., 2017) classifies motivations and satisfaction. The research is the same methodology but has different variables from this study. Then the study of Shavanddasht et al (2017) describes Geotourism as a pleasure, the beauty of geosite, knowledge and uniqueness.

Contributions that can be given by the results of this study to community-based tourism of geoturism can increase economic and social-cultural and the presence of visitors who can provide economic and social-cultural influences. Therefore, the results are enjoyed by the community so that there needs to be an increase in visitors to geotourism such as paying attention to superior products and innovation in community service (Muafi et al., 2018). Furthermore, it is necessary to pay attention to the access of transportation, accommodation, and merchandise as interest strategies of the visitors (Arjana et al., 2017). Academic services also play a role by providing geological information to improve the quality of geotourism in the education sector. Geotourism potential needs to be developed and further investigated because it has the hope of a viable alternative for the income of the community, regional and central government.

\section{CONCLUSION}

This research is intended to describe the development of geotourism and identify economic and social-cultural aspects of community-based tourism in the Tebing Koja and investigate the relevance of influence with geotourism. Based on the literature review with the conceptual framework made in accordance with the methodology. The research findings can be concluded that social-cultural and economy have a significant and positive influence on geotourism. Social-cultural and economic can explain the direct benefits obtained by community-based tourism from the results of the development of geotourism. The existence of social-cultural and economic is able to explain and predict geotourism managed by the community. Social-cultural and economic identification can be analyzed for the causes of geotourism development and can be improved. The results of the study are expected to be able to help the community develop geotourism and natural resources as a whole. The findings of information research for the community, local government and central government in implementing the geotourism development plan can attract both local and foreign visitors.

\section{Acknowlegdments}

The research is under the supervision of the School of Environmental Science of Universitas Indonesia, especially to research cluster "Social System, Human and Environment Interaction". The authors would like to thank the following people for their valuable learnings and comments on this manuscript in the Course of Writing Scientific Environment (Mari Mulyani and Ahyahudin Sodri). The authors would also like to thank the community of Cikuya Village. 


\section{REFERENCES}

Arjana, I.W.B., Ernawati, N.M. \& Astawa, I.K. (2017). Geotourism Products Industry Element: A Community Approach, The 2nd International Joint Conference on Science and Technology (IJCST), September 2728, in Bali, Indonesia.

Aswita, D., Suryadarma, I.G.P. \& Suyanto, S. (2018). Local Wisdom of Sabang Island Society (Aceh, Indonesia) in Building Ecological Intelligence to Support Sustainable Tourism, in GeoJournal of Tourism and Geosites, 22(2), 393-402.

Aquiono, R.S., Schänzel,H.A. \& Hyde, K.F. (2018). Unearthing The Geotourism Experience: Geoutourist perspective at Mount Pinatubo, Philippines, in Tourist Studies, 18(1), 41-62.

Bouzekraoui, H., Barakat, A., Touhami, F., Mouaddine, A. \& El Youssi, M. (2017). Inventory and Assessment of Geomorphosites for Geotourism Development: A Case Study of Aït Bou Oulli Valley (Central High-Atlas, Marocco), in Area, 50(3), 331-343.

Cappucci, M., Pavliashvili, N. \& Zarrilli, L. (2015). New trends in mountain and heritage tourism: The case of upper svaneti in the context of Georgian tourist sector, in GeoJournal of Tourism and Geosites, 15(1), 67-80.

Carvalho, L. \& Costa, T. (2011). Tourism Innovation - A Literature Review Complemented by Case Study Research, in International Conference on Tourism \& Management Studies - ALGARVE, Book of Proceedings I, 23-33.

Chin, H., Lo, M.C., Songan, P. \& Nair, V. (2014). Rural Tourism Destination Competitiveness: A Study on Annah Rais Longhouse Homestay, Sarawak, Paper Presented at 5th Asia-Euro Conference in Tourism, Hospitality and Gastronomy, May 19-21, in Kuala Lumpur, Malaysia.

Cooper, C.P., Fletcher, J.E, Gilbert, D.C. \& Wanhill, S. (2008) Tourism: Principles and Practice, Prentice Hall Financial Times.

Shen, F. \& Cottrell, S.P. (2008) A sustainable tourism framework for monitoring residents' satisfaction with agritourism in Chongdugou Village, China, in Int. J. Tourism Policy, 1(4), 368-375.

Deery, M., Jago, L. \& Fredline, L. (2012). Rethinking Social Impacts of Tourism Research: A New Research Agenda, in Tourism Management, 33, 64-71.

Dowling, R.K. (2013). Global Geotourism - An Emerging Form of Sustainable Tourism, in Czech Journal of Tourism, 2(2), 59-79.

Dowling, R.K. \& Newsome, D. (2010). Global Geotourism Perspective, Oxford, Goodfellow Publishers.

Eraqi, M.I. (2007). Local Communities' Attitudes Towards Impacts of Tourism Development in Egypt, in Tourism Analysis, 12(3), 191-200.

Eshliki, S.A. \& Kaboudi, M. (2012). Community Perception of Tourism Impacts and Their Participation in Tourism Planning: A Case of Ramsar, Iran, Paper Presented at ASEAN Conference on EnvironmentBehaviour Studies, June 15-17, in Bandung, Indonesia.

Farsani, N.T. \& Coelho, C. \& Costa, C. (2012). Geotourism and Geoparks as Gateways to Social-cultural Sustainbility in Qeshm Rural Areas, Iran, in Asia Pasific Journal of Tourism Research, 17(1), 30-48.

Farsani, N.T., Esfahani, M.A.G. \& Shokrizadeh, M. (2018). Understanding Tourists 'Satisfaction and Motivation Regarding Mining Geotours (Case Study : Isfahan , Iran), in Geoheritage, 1-8.

Flecther, J.E., Fyall, A., Gilbert, D. \& Wanhill, S. (2018). Tourism: Principles and Practice, Pearson Education.

Ginting, N. \& Febriandy. (2018). Implementation of Geotourism Concept in Developing Natural Tourist Attraction at Parbaba Village, Toba's Caldera, Paper Presented at Friendly City 4 'From Research to Implementation For Better Sustainbility', October 11-12, in Medan, Indonesia.

Ginting, N. \& Sasmita, A. (2018). Developing Tourism Facilities Based on Geotourism in Silalahi Village, Geopark Toba Caldera, Paper Presented at Friendly City 4 'From Research to Implementation For Better Sustainbility', October 11-12, in Medan, Indonesia.

Ginting, N., Rahman, N.V. \& Sembiring, G. (2017). Tourism Development Based on Geopark in Bakkara Caldera Toba, Indonesia, Paper Presented at 1st Annual Applied Science and Engineering Conference, November 18, in Bandung, Indonesia.

Gordon, J.E. (2012). Rediscovering A Sense of Wonder: Geoheritage, Geotourism and Cultural Landscape Experiences, in Geoheritage, 4(1-2), 65-77.

Hakim, L. \& Soemarno, M. (2017). Biodiversity Conservation, Community Development and Geotourism Development in Bromo-Tengger-Semeru-Arjuno Biosphere Reserve, East Java, in GeoJournal of Tourism and Geosites, 20(2), 220-230.

Hose, T. A., Marković, S. B., Komac, B. \& Zorn, M. (2011). Geotourism - A Short Introduction, in Acta Geographica Slovenica, 51(2), 339-342.

Khan, M.M. (1997). Tourism Development and Dependency Theory: Mass Tourism versus Ecotourism, in Annals of Tourism Research, 24(4), 988-991.

Kodir, A. (2018). Tourism and Development: Land Acquisition, Achievement of Investment and Cultural Change (Case Study Tourism Industry Development in Batu City, Indonesia), in GeoJournal of Tourism and Geosites, 21(1), 253-265. 
Kamarudin, K.H., (2013), Local Stakeholders Participation in Developing Sustainable Community Based Rural Tourism (CBRT): The Case of Three Villages in The East Coast of Malaysia, Paper Presented at Proceedings of International Conference on Tourism Development, February 4-5, in Penang, Malaysia.

Lundberg, E., (2017), The Importance of Tourism Impacts for Different Local Resident Groups: A Case Study of A Swedish Seaside Destination, in Journal of Destination Marketing \& Management, 6, 46-55.

Mero, P.C., Franco, G.H., Briones, J., Caldevilla, P., Domínguez-Cuesta, M.J., \& Berrezueta, E., (2018), Geotourism and Local Development Based on Geological and Mining Sites Utilization, ZarumaPortovelo, Ecuador, in Geosciences, 8 (6).

Muafi, W.T., Wijaya, T., Diharto, A.K., \& Panuntun, B., (2018), Innovation Strategy Role in Tourists Visit Improvement. Context of Man-Made Tourism in Indonesia, in Journal of Environmental Management and Tourism, 9, 304-309.

Organization for Economic Cooperation \& Development (OECD), (2018), OECD Economic Surveys: Indonesia 2018, Paris, OECD Publishing.

Pan, S.Y., Gao, M., Kim, H., Kinjal, J.S., Pei, S., \& Chiang, P., (2018), Advances and challenges in sustainable tourism toward a green economy, Science of the Total Environment, 635, 563-469.

Pralong, J.P., (2006), Geotourism: A new form of tourism utilizing natural landscapes and based on imagination and emotion, in Tourism Review, 61(3), 20-25.

Piacentini, T., Castaldini, D., Coratza, P., Farabollini, P., \& Miccadei, E., (2011), Geotourism: some examples in northern-central Italy, in GeoJournal of Tourism and Geosites, 8(2), 240-262.

Rosyidie, A., Sagala, S., Syahbid, M.M., \& Sasongko, M.A, (2018), The Current Observation and Challenges of Tourism Development in Batur Global Geopark Area, Bali Province, Indonesia, Paper Presented at The 4th PlanoCosmo International Conference, April 3-5, in Bandung, Indonesia.

Rusmana, E., Suwitodirdjo, K., \& Suharsono, (1991), Geological Map of Serang Quadrangle, Java, Scale 1:100.00o, Geological Survey of Indonesia.

Santosh, M., Maruyaman, S., \& Yamamoto, S., (2009), The Making and Breaking of Supercontinents: Some Speculations Based on Superplumes, Super Downwelling and The Role of Tectosphere, in Gowdwana Research, 15(3), 324-341.

Sauders, M., Lewis, P., \& Thornhill, A., (2016), Research Methods for Business Students Seventh Edition, Pearson Education.

Shavanddasht, M., Karubi, M., \& Nekouie, S., (2017), An Examination of The Relationship Between Cave Tourists' Motivations and Satisfaction: The Case of Alisadr Cave, Iran, in GeoJournal of Tourism and Geosites, 2(20), 165-176.

Stokes, A.M., Cook, S., D., \& Drew, D., (2003), Geotourism: The New Trend in Travel, Travel Industry Association of America and National Geographic Traveler.

Pramanik, P.D., Ingkadijaya, R., (2018), The Impact of Tourism on Village Society and its Environmental, Paper Presented at 1st UPI International Geography Seminar 2017, August 8, in Bandung, Indonesia.

Yoon, Y., Gursoy, D., \& Chen, J.S., (2001), Validating A Tourism Development Theory with Structural Equation Modeling, in Tourism Management, 22, 363-372.

Yuliawati, A.K., Pribadi, K.N., \& Hadian M.S.D., (2016), Geoturism Resources as Part of Sustainable Development in Geopark Indonesia, in Proceedings of the 2016 Global Conference on Business, Management and Entrepreneurship, August 8, in Bandung, Indonesia.

Vinodan, A., Manalel, J., \& Meera, S., (2017), Factorial structure of community intervention strategies in ecotourism, in Journal of Environmental Management and Tourism, 73, 590-605.

** Asia-Pacific Economic Cooperation (APEC), (2000), 2000 APEC tourism ministerial meeting: Seoul declaration on an APEC Tourism Charter. https://apec.org/Meeting-Papers/Sectoral-MinisterialMeetings/Tourism/200o_tourism, acceced on 12 Agust 2019

*** The Mountain Institute, (2000), Community-Based Tourism for Conservation and Development: A Resource Kit, The Mountain Institute.

*** Tsiotsou, R.H., Goldsmith, R.E., (2012), Strategic Marketing in Tourism Service First Edition, Emerald Group Publising.

Submitted:

03.09.2019
Revised:

12.02.2020
Accepted and published online 19.02.2020 